\title{
Rasa Aman Sebagai Prediktor Kepercayaan Masyarakat dengan Hadirnya Polisi
}

\author{
Ditta Febrieta, Yuarini Wahyu Pertiwi \\ ditta.febrieta@dsn.ubharajaya.ac.id
}

Fakultas Psikologi, Universitas Bhayangkara Jakarta Raya, Jakarta, Indonesia

\begin{abstract}
The spread of information or people's direct experience with police will affect police image, either negative or positive. Unpleasant police behavior can cause distrust among people who are perceiving that police should act with good governance characteristics, with their main responsibility to protect and serve community. The feeling of distrust will make people feel insecured or even feared with the presence of police. This study aims to investigate the role of the sense of feeling secured to the public trust towards police presence. One hundred and fifty six participants were recruited from civil society. Scales to measure trust and the sense of feeling secured were employed to collect data from participants. This study was using quantitative approach with regression analysis technique. The results showed positive correlation between both variables, with the sense of feeling secured contributed 71 percent to the variable of public trust to police.
\end{abstract}

Keywords: police; security; trust

Beredarnya informasi ataupun pengalaman yang langsung dialami masyarakat akan memberikan pengaruh terhadap citra kepolisian, baik berupa citra negatif maupun positif. Tindakan polisi yang kurang baik akan menimbulkan ketidakpercayaan masyarakat terhadap keberadaan polisi yang semestinya memliki karakteristik good governance, dengan tugas melindungi, mengayomi, dan melayani masyarakat. Perasaan tidak percaya tersebut akan membuat masyarakat menjadi merasa tidak aman bahkan merasa takut jika ada polisi di dekatnya. Penelitian ini bertujuan untuk mengetahui peran rasa aman dalam memengaruhi kepercayaan masyarakat terhadap kehadiran polisi. Subjek penelitian ini adalah masyarakat sipil berjumlah 156 orang. Skala Kepercayaan dan Skala Rasa Aman digunakan untuk mengumpulkan data. Metode penelitian ini menggunakan penelitian kuantitatif dengan teknik analisis regresi. Hasil penelitian menunjukkan adanya korelasi positif antara kedua variabel, dengan rasa aman memberikan sumbangan efektif sebesar 71 persen terhadap kepercayaan masyarakat terhadap kehadiran polisi.

Kata kunci: kepercayaan; polisi; rasa aman

Received: August 23, 2018 Accepted: December 12, 2018

How to cite: Febrieta, D., \& Pertiwi, Y. W. (2018). Rasa Aman Sebagai Prediktor Kepercayaan Masyarakat dengan Hadirnya Polisi. MEDIAPSI, 4(2), 68-75. doi:

https://doi.org/10.21776/ub.mps.2018.004.02.2

\section{Pendahuluan}

Pandangan masyarakat terhadap kinerja polisi dapat berupa penilaian positif maupun negatif tergantung aspek dan dimensinya. Terkait pemberantasan perjudian, penangkapan teroris, dan perlindungan terhadap aksi kriminalitas pencurian, pada umumnya kinerja polisi dinilai masyarakat baik. Tetapi ada juga yang dinilai buruk oleh masyarakat, terutama dalam hal-hal yang berkaitan dengan penanggulangan korupsi di tubuh kepolisian itu sendiri, pemerasan oleh oknum polisi, dan tindakan illegal mining serta penyelundupan. Hal tersebut seperti pernyataan yang diungkapkan oleh Khoidin \& Sadjijono (2006) bahwa tindakan polisi seperti itu dinilai telah menyimpang dari jati dirinya sebagai anggota kepolisian dan merusak citra polisi di mata masyarakat.

Penilaian baik atau buruk masyarakat 
terhadap kepolisian adalah akibat dari ketidakmampuan dan ketidakberhasilan menjadi pengayom masyarakat. Bagi masyarakat, polisi yang dikatakan berkarakter terpuji adalah yang dapat menempatkan diri sebagai seorang moralis, bapak/ibu, teman, pengabdi, dan tokoh yang dikagumi dan dihormati. Artinya, kemuliaan martabat dan kehormatan polisi dapat dilihat dari besarnya penghargaan dan pengakuan masyarakat terhadap profesinya. Penghargaan yang sesungguhnya tercermin dalam realitas perilaku pengabdian dan pelaksanaan tugasnya yang membawa manfaat bagi masyarakat, bahkan ditempatkan secara terhormat di tengah kehidupan masyarakat.

Memaknai hal tersebut, satu masalah sosial yang terjadi di Indonesia adalah munculnya perasaan tidak percaya dengan polisi di tengah masyarakat. Seharusnya, masyarakat merasa aman dengan kehadiran polisi dan bisa memercayai polisi sebagai pelindung masyarakat yang menciptakan maupun meningkatkan keamanan namun kenyataaanya beragam kritik pedas masih menerpa korps kepolisian hingga kini. Derasnya arus pesimisme masyarakat terhadap kepolisian penting untuk dicatat karena kalangan internal kepolisian sendiri dianggap kurang tanggap membenahi diri. Hubungan polisi dengan masyarakat pun belum kunjung mesra. Kerinduan masyarakat terhadap polisi seolah berganti menjadi kebencian yang menimbulkan hubungan yang buruk antara kedua belah pihak. Kebencian yang muncul dari masyarakat dikarenakan rasa percaya mereka yang rendah terhadap kinerja Polisi. Dewasa ini, banyak masyarakat yang terdoktrin bahwa berurusan dengan polisi akan semakin merugikan. Salah satunya adalah kasus pencurian di mana barang bukti terkait pencurian yaitu televisi milik korban harus diserahkan kepada polisi namun tidak ditentukan waktu pengembaliannya. Hal tersebut membuat korban merasa kesal dan rumah korbanpun diberikan garis polisi yang apabila ingin dicopot perlu membayar sejumlah uang kepada pihak polisi (Adi, 2011).

Hal tersebut sejalan dengan hasil survei dari Lembaga Survei Indonesia pada tahun 2013 terhadap 1100 responden di 33 provinsi bahwa masyarakat yang percaya terhadap Polisi hanya sebesar 2.87 persen. Gambar 1 menunjukkan bahwa ketidakpercayaan masyarakat kepada polisi terkait dengan masalah menangani korupsi, aksi kejahatan dan pemberantasan narkoba, disusul oleh pelanggaran HAM yang dilakukan oleh aparat dan pemberantasan pornografi.

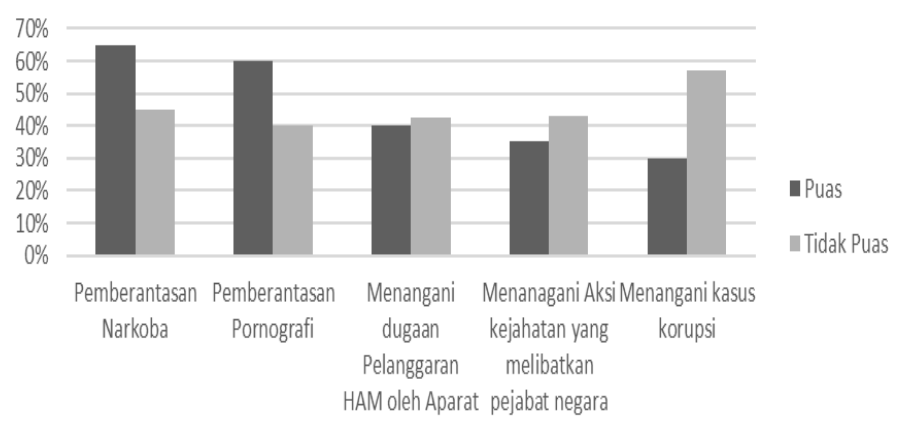

Gambar 1. Tingkat Kepercayaan Masyarakat Terhadap Polisi (Lembaga Survey Indonesia, 2015)

Rasa percaya masyarakat terhadap polisi akan memberi dampak positif pada kedua belah pihak baik masyarakat maupun polisi. Kepercayaan adalah timbal balik keyakinan niat dan perilaku orang lain (Kreitner \& Kinicki, 2007). Hubungan timbal balik ini terjadi ketika seseorang melihat orang lain berperilaku yang menyiratkan bahwa ia dapat dipercaya, maka orang tersebut akan membalas dengan memberikan perasaan percaya. Perasan percaya pada diri individu akan membentuk hubungan interpersonal yang berkualitas. Hal ini senada dengan hasil 
penelitian dari Gounaris dan Venetis (2002) yang menyatakan bahwa kepercayaan merupakan faktor penting dalam menjalin hubungan secara timbal balik. Sebagai contoh, ketika ada tawuran dan polisi berperilaku bahwa mereka siap melindungi warga di sekitar, maka warga pun akan memercayakan situasi tersebut kepada polisi agar tawuran dapat dihentikan. Terciptanya hubungan yang baik antara masyarakat dan polisi dapat berakibat kepada kondisi timbal baik yang tepat di mana keduanya bisa menerima dan menghargai satu sama lain.

Kepercayaan dalam menjalin relasi merupakan hal penting dalam kehidupan sosial namun akan ada beberapa orang yang sulit untuk dipercaya, seperti rendahnya kepercayaan pada institusi kepolisian (Brehm \& Rahn, 1997). Namun, penelitian yang dilakukan oleh Suryadi (2013) mengemukakan bahwa memercayai orang lain saat ini masih dianggap berharga dan sangat penting untuk dilakukan meskipun sulit untuk mampu memercayai orang lain karena adanya kekecewaan dan perasaan takut dikecewakan lagi.

Rasa percaya masyarakat yang kurang terhadap polisi merupakan masalah yang harus segera dituntaskan oleh institusi kepolisian. Hal tersebut senada dengan apa yang dikatakan oleh mantan ketua Mahkamah Konstitusi, Jimly Asshiddiqie, bahwa tugas berat yang akan dipikul oleh pimpinan kepolisian adalah mengembalikan kepercayaan masyarakat Indonesia (Pravita, 2015). Menurut Rotter (dalam Lewicki \& Wiethoff, 2000), faktor yang memengaruhi tumbuhnya rasa percaya adalah predisposisi kepribadian, reputasi dan stereotip, pengalaman aktual, serta orientasi psikologis. Berkaitan dengan penelitian ini, masyarakat bisa memiliki rasa percaya kepada polisi ketika memiliki orientasi psikologis yang positif terhadap polisi, yaitu kondisi hubungan emosi yang positif dalam bentuk rasa aman.

Maslow (dalam Potter \& Perry, 2005) mendefinisikan rasa aman sebagai perasaan terlindungi dari ancaman atau teror dari luar dan dalam dirinya terkait dengan keamanan. Rasa aman merupakan sesuatu kebutuhan yang mendorong individu untuk memperoleh ketentraman, kepastian dan keteraturan dari keadaan lingkungan. Kebutuhan rasa aman tidak sebatas pada keamanan fisik, melainkan juga keamanan yang menyangkut psikologis yang di dalamnya berhubungan dengan jaminan keamanan, stabilitas sistem yang menghindarkan manusia dari rasa cemas, khawatir dan berbagai hal lainnya. Selain itu, Maslow (2010) berpendapat bahwa rasa aman merupakan salah satu kebutuhan yang meliputi kebutuhan untuk dilindungi dan jauh dari sumber bahaya, baik berupa ancaman fisik maupun psikologis.

Perasaan aman kepada aparatur negara menjadi hal penting dalam memengaruhi kepercayaan. Ketika masyarakat tidak merasa aman dengan hadirnya polisi maka kepercayaan masyarakat tidak akan muncul dalam diri masyarakat. Pasal 13 Undangundang No. 2 Tahun 2002 tentang Kepolisian Negara Republik Indonesia yang menyebutkan bahwa "tugas pokok Kepolisian Negara Republik Indonesia adalah (a) memelihara keamanan dan ketertiban masyarakat (b) menegakkan hukum dan (c) memberikan perlindungan, pegayoman, dan pelayanan kepasa masyarakat". Dengan demikian, sudahlah menjadi keharusan bahwasanya kepolisian bisa memberikan rasa aman kepada masyarakat agar bisa mendapat kepercayaan sebagai aparat penegak hukum. Dalam teori kebutuhan, Maslow (dalam Feist, Feist, \& 
Robert, 2017) mengatakan bahwa penghargaan akan muncul apabila sudah terbentuk rasa aman oleh masyarakat terhadap fungsi tugas polisi.

Hubungan antara polisi dan masyarakat sering diibaratkan sebagai ikan dan air, yang bermakna bahwa keduanya saling membutuhkan satu sama lain. Dengan demikian, memperoleh dukungan yang ikhlas dari masyarakat menjadi sangat penting untuk kelancaran tugas, sesuai dengan yang diamanatkan doktrin polisi mutakhir yaitu shaking hands with the entire community (Rahardjo, 2007). Oleh karena itu, kerjasama polisi dan masyarakat memerlukan timbal balik yaitu masyarakat yang merasa aman dengan hadirnya polisi dan kemudian akan menumbuhkan rasa percaya terhadap polisi serta secara profesional polisi akan lebih baik dalam melindungi, melayani, dan mengayomi.

Namun demikian, apakah benar bahwa rasa aman masyarakat terhadap kepolisian sudah tidak ada sama sekali sehingga masyarakat tidak percaya lagi atas bantuan yang diberikan dari kepolisian? Seperti yang sudah diuraikan sebelumnya bahwa masyarakat merasa tidak aman dengan hadirnya polisi karena takut ditilang atau dirugikan secara materi dan bahkan sebagian masyarakat pun merasa polisi tidak mampu mengerjakan tugasnya dengan baik. Tugas polisi dengan karakteristik good governance sepertinya siasia dengan tiga fungsi utamanya. Keadaan tersebut kemudian memunculkan perasaan bahwa kepolisian tidak dapat dipercaya untuk mengatasi permasalahan yang dihadapi masyarakat. Berdasarkan pertanyaan tersebut, maka penelitian ini bertujuan untuk mengetahui peran rasa aman yang dirasakan masyarakat terhadap kepercayaan kepada hadirnya polisi.

\section{Metode}

\section{Desain penelitian}

Penelitian ini menggunakan pendekatan kuantitatif korelasional, yang bertujuan untuk mengetahui hubungan antara satu variabel dengan variabel lainnya.

\section{Partisipan}

Seratus lima puluh enam orang berpartisipasi dalam penelitian ini. Keseluruhan partisipan adalah warga sipil (non-polisi).

\section{Instrumen penelitian}

Skala yang digunakan dalam penelitian ini adalah Skala Rasa Aman yang disusun dengan menggunakan komponen yang dipaparkan oleh Maslow seperti stabilitas, perlindungan fisik, perlindungan emosi, dan struktur dan batas. Skala Rasa Aman terdiri dari 24 butir model Likert dengan lima alternatif jawaban dari sangat sesuai hingga sangat tidak sesuai. Contoh butir pada skala tersebut antara lain: "kekhawatiran saya berkurang ketika ada polisi di jalan”. Rentang skor butir-total pada skala ini sebesar 0.3560.795 dan skor Alpha Cronbach sebesar 0.943.

Instrumen penelitian berikutnya adalah Skala Kepercayaan yang disusun dengan menggunakan komponen rasa percaya yang dipaparkan oleh Borum seperti komponen kepercayaan yang melingkupi tingkat kepercayaan dan integritas, komponen kognitif, dan komponen afektif. Skala Kepercayaan terdiri dari 30 butir dan 28 butir dinyatakan valid dengan rentang skor butirtotal sebesar 0.308-0.794 dan skor Alpha Cronbach sebesar 0.960. Skala kepercayaan juga menggunakan model Likert dengan lima alternatif jawaban dari sangat sesuai hingga sangat tidak sesuai. Contoh butir pada skala ini antara lain seperti: "saya yakin polisi bisa 
mengatur lalu lintas dengan baik”.

\section{Teknik analisis data}

Uji hipotesis penelitian ini dilakukan dengan teknik regresi. Sebelum uji regresi dilakukan, uji korelasi dan uji $\mathrm{F}$ terlebih dahulu.

\section{Hasil}

Tabel 1 menampilkan proporsi subjek penelitian yang terdiri dari 156 orang dengan jumlah perempuan mendominasi sebesar $71.8 \%$ (112 orang) dibandingkan laki-laki sebesar $28.2 \%$ (44 orang).

Tabel 1

Kategorisasi Subjek Penelitian

\begin{tabular}{lcc}
\hline & Frekuensi & Persentase \\
\hline Perempuan & 112 & $71.8 \%$ \\
Laki-laki & 44 & $28.2 \%$ \\
\hline Total & 156 & $100 \%$ \\
\hline
\end{tabular}

Sebelum uji regresi dilakukan maka perlu dilakukan uji korelasi dan uji $F$. Sebagaimana yang dapat dilihat di Tabel 2, diperoleh skor koefisien korelasi Pearson sebesar 0.843 yang menyatakan terdapat hubungan positif antara rasa aman dengan kepercayaan. Artinya, semakin tinggi rasa aman masyarakat maka semakin tinggi pula kepercayaan masayarakat terhadap hadirnya polisi. Hasil analisis menunjukkan hubungan yang kuat karena skor korelasi mendekati angka 1.

Uji F dilakukan untuk menentukan layak tidaknya analisis regresi dilakukan. Berdasarkan hasil analisis (lihat Tabel 3), tampak bahwa skor pada uji model regresi atau dikenal sebagai uji $\mathrm{F}$ diperoleh skor sebesar 376.866 dengan signifikansi <0.01. Artinya, model regresi yang dibuat dari variabel rasa aman dan variabel kepercayaan adalah signifikan.
Tabel 2

Koefisien Korelasi

\begin{tabular}{llcc}
\hline & & \multicolumn{1}{c}{$\begin{array}{c}\text { Rasa } \\
\text { Aman }\end{array}$} & $\begin{array}{c}\text { Keperca } \\
\text {-yaan }\end{array}$ \\
\hline Rasa Aman & $\begin{array}{l}\text { Pearson } \\
\text { Correlation }\end{array}$ & 1 & $.843^{* *}$ \\
\cline { 2 - 4 } & Sig. (2-tailed) & & .000 \\
\cline { 2 - 4 } & $\mathrm{N}$ & 156 & 156 \\
\hline Kepercayaan & $\begin{array}{l}\text { Pearson } \\
\text { Correlation }\end{array}$ & $.843^{* *}$ & 1 \\
\cline { 2 - 4 } & Sig. (2-tailed) & .000 & \\
\cline { 2 - 4 } & $\mathrm{N}$ & 156 & 156 \\
\hline i* significant at the 0.011 level (2-tailed)
\end{tabular}

Tabel 3

Uji Model Regresi

ANOVA $^{\mathrm{a}}$

\begin{tabular}{llccccc}
\hline Model & $\begin{array}{c}\text { Sum of } \\
\text { Squares }\end{array}$ & df & $\begin{array}{c}\text { Mean } \\
\text { Square }\end{array}$ & F & Sig. \\
\hline 1 & Regre- & 35452.645 & 1 & 35452. & 376. & $.000^{\mathrm{b}}$ \\
& ssion & & & 645 & 866 & \\
& Residual & 14487.125 & 154 & 94.072 & & \\
& Total & 49939.769 & 155 & & & \\
\end{tabular}

${ }^{a}$ Dependent variable: kepercayaan

bPredictors: (constant), rasa aman

Berdasarkan hasil uji koefisien determinasi (lihat Tabel 4), diperoleh skor $\mathrm{R}$ Square sebesar 0.710. Artinya, rasa aman memberikan sumbangan efektif sebesar $71 \%$ dalam memengaruhi kepercayaan masyarakat terhadap hadirnya polisi. Hal ini mengindikasikan bahwa rasa aman memberikan pengaruh yang kuat terhadap kepercayaan.

Berdasarkan analisis sebagaimana ditunjukkan pada Tabel 5 tampak bahwa perolehan data di atas dapat dibuat persamaan regresinya sebagai berikut:

$$
\mathrm{Y}=\mathrm{a}+\mathrm{bX} 1=3.901+1.031 \mathrm{X} 1
$$

Persamaan tersebut menyatakan bahwa rasa percaya mayarakat kepada polisi diperoleh skor sebesar 3.901, sehingga setiap 
kenaikan satu poin pada rasa aman (X1) masyarakat maka rasa percaya (Y) masyarakat kepada kehadiran polisi meningkat 1.031 poin.

Tabel 4

Uji Koefisien Determinasi

\begin{tabular}{ccccc}
\hline Model & R & $\begin{array}{c}\text { R } \\
\text { Square }\end{array}$ & $\begin{array}{c}\text { Adjusted } \\
\text { R Square }\end{array}$ & $\begin{array}{c}\text { Std. Error } \\
\text { of the } \\
\text { Estimate }\end{array}$ \\
\hline 1 & $.843^{\mathrm{a}}$ & .710 & .708 & 9.69908 \\
\hline
\end{tabular}

aPredictors: (constant), rasa aman

Tabel 5

Koefisien Beta

\begin{tabular}{|c|c|c|c|c|c|c|}
\hline & \multirow[t]{2}{*}{ Model } & \multicolumn{2}{|c|}{ Unstand. Coeff. } & \multirow{2}{*}{$\begin{array}{c}\begin{array}{c}\text { Stand. } \\
\text { Coeff. }\end{array} \\
\text { Beta }\end{array}$} & \multirow[t]{2}{*}{$\mathbf{t}$} & \multirow[t]{2}{*}{ Sig. } \\
\hline & & B & $\begin{array}{l}\text { Std. } \\
\text { Error }\end{array}$ & & & \\
\hline \multirow[t]{2}{*}{1} & (Constant) & 3.901 & 3.344 & & 1.167 & .245 \\
\hline & $\begin{array}{l}\text { Rasa } \\
\text { Aman }\end{array}$ & 1.031 & .053 & .843 & 19.413 & .000 \\
\hline
\end{tabular}

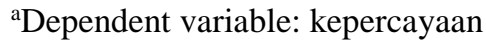

Berdasarkan hasil uji beda (lihat Tabel 6), tidak ditemukan adanya perbedaan yang signifikan $(>0.05)$ antara perempuan dan lakilaki baik pada variabel kepercayaan dan rasa aman. Perbedaan rerata pada variabel rasa aman sebesar 1.62338 dan pada variabel kepercayaan sebesar 3.69399.

Pada Tabel 7 tampak bahwa rasa aman masyarakat berada dalam kategori sedang sebesar $52.6 \%$ (82 orang), dilanjutkan dengan kategori tinggi sebesar $44.9 \%$ (70 orang), dan yang paling rendah hanya $2.6 \%$ (4 orang). Hal ini mengindikasikan bahwa hanya sedikit masyarakat yang merasa tidak aman dengan hadirnya polisi. Begitu pula pada variabel kepercayaan (lihat tabel 8) dengan kategorisasi paling tinggi berada dalam kategori sedang dengan jumlah $67.9 \%$ (106 orang), dilanjuti dengan kategori tinggi sebesar 28.2\% (44 orang), dan yang paling rendah berjumlah $3.8 \%$ (4 orang). Hal ini mengindikasikan bahwa kepercayaan masyarakat berada didominasi pada kategori sedang.

Tabel 6

Uji Beda Rasa Aman dan Rasa Percaya Berdasarkan Jenis Kelamin

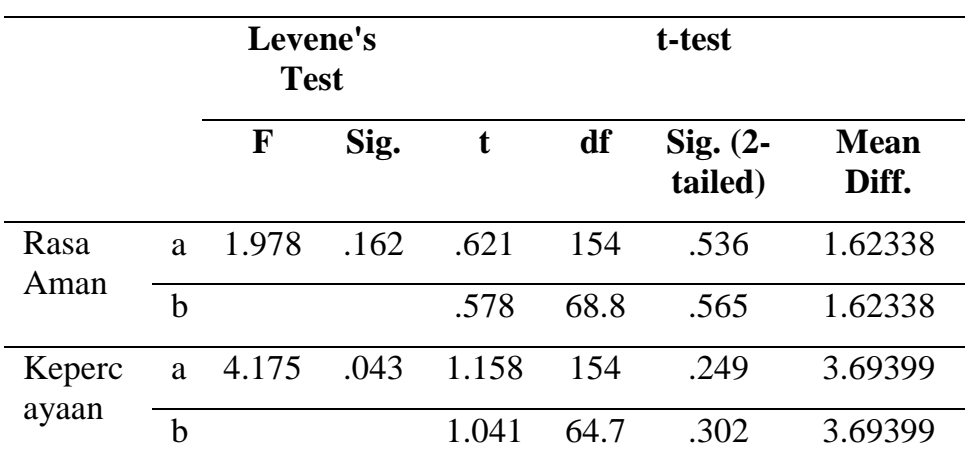

(a) Equal variances assumed

(b) Equal variances not assumed

Tabel 7

Uji Kategorisasi Variabel Rasa Aman

\begin{tabular}{ccccc}
\hline \multirow{2}{*}{ Valid } & & Frequency & Percent. & Valid Percent. \\
\cline { 2 - 5 } & Tinggi & 70 & 44.9 & 44.9 \\
\cline { 2 - 5 } & Sedang & 82 & 52.6 & 52.6 \\
\cline { 2 - 5 } & Rendah & 4 & 2.6 & 2.6 \\
\cline { 2 - 5 } & Total & 156 & 100.0 & 100.0 \\
\hline
\end{tabular}

Tabel 8

Uji Kategorisasi Variabel Kepercayaan

\begin{tabular}{llccc}
\hline \multirow{3}{*}{ Valid } & & Frequency & Percent. & Valid Percent. \\
\cline { 2 - 5 } & Tinggi & 44 & 28.2 & 28.2 \\
\cline { 2 - 5 } & Sedang & 106 & 67.9 & 67.9 \\
\cline { 2 - 5 } & Rendah & 6 & 3.8 & 3.8 \\
\cline { 2 - 5 } & Total & 156 & 100.0 & 100.0 \\
\hline
\end{tabular}

\section{Diskusi}

Penelitian ini melibatkan 156 orang dengan jumlah perempuan mendominasi sebesar $71.8 \%$ (112 orang) dibandingkan lakilaki sebesar 28.2\% (44 orang). Berdasarkan hasil uji t dengan analisis sampel independen tidak ditemukan adanya perbedaan berdasarkan jenis kelamin baik pada variabel rasa aman maupun variabel kepercayaan dengan taraf signifikansi lebih besar dari 0.05. 
Hal ini dapat dikarenakan jumlah subjek yang kurang proposional antara perempuan dan laki-laki, serta perbedaan rerata yang tidak terlalu besar. Pada uji korelasi ditemukan adanya hubungan positif yang kuat di antara variabel dan sumbangan efektif variabel bebas, yaitu variabel rasa aman, sebesar 0.843. Hal tersebut mengindikasikan bahwa semakin tinggi rasa aman yang dimiliki masyarakat maka akan meningkatkan rasa percaya masyarakat kepada polisi. Hubungan yang kuat tersebut disimpulkan dari skor koefisien korelasi yang mendekati angka 1. Pada uji koefisien determinasi ditemukan bahwa sumbangan efektif variabel rasa aman sebesar $71 \%$ kepada variabel kepercayaan. Angka tersebut cukup besar karena hampir mendekati angka $100 \%$. Artinya, 29\% sumbangan lainnya adalah variabel yang tidak termasuk pada penelitian ini yaitu kepribadian, reputasi dan stereotip, serta pengalaman aktual.

Berdasarkan hasil kategorisasi ditemukan bahwa baik pada variabel kepercayaan dan rasa aman, mayoritas berada pada kategori sedang. Hal ini dapat disebabkan subjek penelitian ini bersifat homogen, yaitu sesuai dengan karakteristik penelitian. Namun jika dilihat lebih lanjut, masyarakat yang memiliki kepercayaan yang tinggi kepada polisi (kategori tinggi) hanya berkisar $28.2 \%$ (44 orang) dan sisanya sebesar 3.8\% (6 orang) memilih untuk kurang percaya dengan polisi (kategori rendah). Hasil ini senada dengan penelitian yang dilakukan oleh Suryadi (2013) yang mengemukakan bahwa memercayai orang lain dianggap berharga dan sangat penting untuk dilakukan meskipun sulit untuk mempercayai orang lain karena adanya kekecawaan dan perasaan takut dikecewakan lagi. Dalam hal ini, polisi merupakan bagian dari negara yang memiliki ragam pandangan positif dan negatif dari masyarakat namun tetap saja masyarakat percaya dengan polisi bahwa polisi akan mengerjakan tugasnya dengan karakteristik good governance. Rasa percaya masyarakat ini dipengaruhi oleh rasa aman yang dirasakan oleh masyarakat yang tampak bahwa $44.9 \%$ (70 orang) berada dalam kategori tinggi dan 52.6\% (82 orang) berada dalam kategori sedang. Hanya 2.6\% (4 orang) merasa tidak aman dengan kehadiran polisi yang mungkin dikarenakan pengalaman pribadi yang tidak menyenangkan dengan oknum polisi yang menyalahi wewenang.

\section{Daftar Pustaka}

Adi, W. (2011, Desember). Polisi, Berpihaklah pada Korban. Kompas.com. Diambil dari:

https://megapolitan.kompas.com/read/2 011/12/05/06354835/Polisi.Berpihaklah .kepada.Korban

Brehm, J., \& Rahn, W. (1997). Individuallevel evidence for the causes and consequences of social capital. American Journal of Political Science, 41(3), 9991023.

doi: https://doi.org/10.2307/2111684

Feist, J., Feist, G. J., \& Roberts, T. A. (2017). Teori Kepribadian Edisi Kedelapan. Jakarta: Salemba Humanika.

Gounaris, S., \& Venetis, K. (2002). Trust in industrial service relationships: Behavioral consequences, antecedents and the moderating effect of the duration of the relationship. Journal of Service Marketing, 16(7), 636-655. doi: https://doi.org/10.1108/0887604021044 $\underline{7351}$

Khoidin, M., \& Sadjijono. (2006). Mengenal Figur Polisi Kita. Yogyakarta: Laksbang 
PRESSindo.

Kreitner, R., \& Kinicki, A. (2007). Organizational Behavior Edisi Ketujuh. NewYork: McGraw-Hill.

Lembaga Survei Indonesia. (2015). Tingkat Kepercayaan Masyarakat Terhadap Polisi. Diambil dari: http://www.1si.or.id/

Lewicki, R. J., \& Wiethoff, C. (2000). Trust, trust development, and trust repair. Dalam M. Deutsch \& P. T. Coleman (Eds.), Handbook of Research Conflict Resolution: Theory and Practice (hal. 86-107). San Francisco, CA: JosseyBass.

Maslow, A. (2010). Motivation and Personality. Jakarta: Rajawali.

Potter, P. A., \& Perry, A. G. (2005). Buku Ajar Fundamental Keperawatan: Konsep, Proses, dan Praktik Edisi Keempat. Jakarta: EGC.

Pravita, D. (2015, April). Tugas Kapolri Baru Mengembalikan Kepercayaan Dan Rasa Aman Masyarakat. NRM News. Diambil dari:

https://nrmnews.com/2015/04/18/tugaskapolri-baru-mengembalikan-

kepercayaan-dan-rasa-amanmasyarakat/

Rahardjo, S. (2007). Mengkaji Kembali Peran dan Fungsi Polri dalam Masyarakat di Era Reformasi. Jakarta: Kompas Gramedia.

Rahayu, M. (2007). Pendidikan Kewarganegaraan. Jakarta: Grasindo.

Suryadi, D. (2013). Trustworthiness in relationship: Recent study on social behavior. Paper presented at the 3rd Asian Conference on Psychology and the
Behavioral Sciences, Osaka, Jepang. Diambil dari: https://www.researchgate.net/publicatio n/264558660_TRUSTWORTHINESS IN_RELATIONSHIP_RECENT_STU DY_ON_SOCIAL_BEHAVIOR 